\title{
Analisis Video Comments to Video Views Ratio Youtube Pada 5 Youtuber Gaming Top di Indonesia dengan Penghasilan Tinggi
}

\author{
Fachmi Hidayatulloh \\ fahmi09familia@gmail.com
}

\begin{abstract}
Youtube is a website that facilitates users to share the videos they have, or just enjoy various video clips uploaded by various parties. There are various kinds of videos that can be uploaded to this site, such as music video clips from certain musicians, short films, television films, film trailers, educational videos, video blogs belonging to vloggers, video tutorials for various activities, and much more. Many think that playing online games or console games hinders one's success. In fact, there are many Indonesian gaming YouTubers who gain a lot of benefits after uploading their game activities on the YouTube channel. Not a few have won awards at the international level. The content they upload also varies. There are those who create gameplay content, tips on playing games, game recommendations, to fun tutorials! All of this is not only entertaining, but also adds insight to the audience as gamers. The 5 Top Gaming Youtubers in Indonesia with High Income, namely: Jess No Limit, MiawAug., Tara Arts Game Indonesia, Dylan PROS and Kemas use Z. This study aims to calculate the credibility of the account performance of the Top 5 Youtuber Gaming Youtubers in Indonesia with Income Tall. The method used for this research is quantitative exploratory method.
\end{abstract}

\begin{abstract}
ABSTRAK
Youtube adalah sebuah website yang menfasilitasi penggunanya untuk berbagi video yang mereka miliki, atau sebatas menikmati berbagai video klip yang diunggah oleh berbagai pihak. Terdapat berbagai macam video yang dapat diunggah ke situs ini, seperti misalnya video klip musik dari musisi tertentu, film pendek, film televisi, trailer film, video edukasi, video blog milik para vlogger, video tutorial berbagai macam aktivitas, dan masih banyak lagi. Banyak yang beranggapan bahwa main game online atau game konsol menghambat kesuksesan seseorang. Padahal, ada banyak YouTuber gaming Indonesia yang meraih banyak keuntungan setelah mengunggah aktivitas game-nya di kanal YouTube. Tak sedikit pula yang sudah meraih penghargaan hingga ke tingkat internasional. Konten yang mereka unggah pun beragam. Ada yang membuat konten gameplay, tips dalam bermain game, rekomendasi game, hingga tutorial-tutorial yang asyik! Semua itu tidak hanya menghibur, tetapi juga menambah wawasan penonton sebagai gamers. Adapun 5 Youtuber Gaming Top di Indonesia dengan Penghasilan Tinggi, yaitu : Jess No Limit, MiawAug., Tara Arts Game Indonesia, Dylan PROS dan Kemas pakai Z. Penelitian ini bertujuan untuk menghitung kredibilitas dari performa akun Youtube 5 Youtuber Gaming Top di Indonesia dengan Penghasilan Tinggi. Metode yang digunakan untuk penelitian ini yaitu metode eksploratif kuantitatif.
\end{abstract}




\section{PENDAHULUAN}

Teknologi informasi dan komunikasi yang telah berkembang pesat mampu mengahntarkan manusia untuk menciptakan bentuk baru cara berkomunikasi dan berinteraksi. Teknologi komunikasi dan informasi merupakan aplikasi pengetahuan dan keterampilan yang digunakan manusia dalam mengalirkan informasi atau pesan dengan tujuan untuk membantu menyelesaikan permasalahan manusai agar tercapai tujuan komunikasi.

Semakin berkembangnya kecanggihan teknologi informasi dan komunikasi menyebabkan terjadinya perubahan budaya masyarakat sehari-hari, perkembangan tersebut tidak terlepas dari penggunaan media bagi kegiatan manusia dalam bidang ekonomi, sosial, politik dan budaya. Media sosial sangat berpengaruh pada kehidupan berinteraksi saat ini, sehingga aplikasi media sosial saat ini ada berbagai macan dengan fungsi dan fitur yang berbeda-beda. Aplikasi sosial media yang sering digunakan adalah Twitter, Instagram, YouTube, WhatsApp, Telegram dan lain sebagainya. Salah satu aplikasi sosial media yang paling banyak memiliki peminat yaitu YouTube (Hendika Permana 2021).

Salah satunya adalah aplikasi youtube, yang memberikan kemudahan masyarakat dunia untuk mendapatkan informasi yang luas (Mangole, Himpong, dan Kalesaran 2017). Kemajuan Youtube di Indonesia sangat lah pesat sehingga setiap orang dapat memiliki akun Youtube nya sendiri. Sangat banyak orang dengan keahlian memainkan sebuah permainan atau Games membuat akun Youtube untuk menunjukan skill dan dari akun youtube mereka mendapatkan penghasilan. Adapun 5 Youtuber Gaming Top di Indonesia dengan Penghasilan Tinggi, diantaranya yaitu : Jess No Limit, MiawAug., Tara Arts Game Indonesia, Dylan PROS dan Kemas pakai Z ("5 Youtuber Gaming Top di Indonesia dengan Penghasilan Tinggi - (Suarasumsel.com 2021)”).

Penelitian ini menggunakan metode eksploratif kuantitatif, dan akan menghitung menggunakan rasiorasio yang ada pada Youtube. Penelitian ini hanya berfokus untuk menghitung kredibilitas Video Comments to Video Views Ratio pada 5 Youtuber Gaming Indonesia dengan Penghasilan Tinggi. Adapun 5 Youtuber Gaming Top di Indonesia dengan Penghasilan Tinggi, diantaranya yaitu : Jess No Limit, MiawAug., Tara Arts Game Indonesia, Dylan PROS dan Kemas pakai Z (“5 Youtuber Gaming Top di Indonesia dengan Penghasilan Tinggi -(Suarasumsel.com 2021)”). Tujuan dari penelitian ini adalah mengetahui kredibilitas performa dari akun Youtube 5 Youtuber Gaming di Indonesia dengan Penghasilan Tinggi menggunakan Video Comments to Video Views Ratio. Penelitian ini berjudul "5 Youtuber Gaming Top di Indonesia dengan Penghasilan Tinggi” sebagai objek. Penulis mendapatkan berita yang bersumber dari link : https://sumsel.suara.com/read/2021/10/04/130633/ini-5-youtubergaming-paling-top-di-indonesia-penghasilan-tinggi. 


\section{TINJAUAN PUSTAKA}

Teknologi terus berkembang seiring berkembangan zaman. Perkembangan teknologi ini menghasilkan platform- platform media sosial dengan fitur beraneka ragam. Salah satu platform yang sangat diminati oleh banyak kalangan yaitu Youtube. Youtube sangat mudah diakses oleh banyak kalangan. Bahkan anak kecil pun dapat menggunakan platform ini. Oleh karena itu, platform Youtube ini sangat banyak yang meminati.YouTube merupakan salah satu situs berbagi video daring (dalam jaringan) terbesar di dunia ini diprakarsai oleh tiga orang mantan pegawai PayPal di tahun 2005 untuk membuat media sosial dimana pengguna bisa mengunggah video (Mangole, Himpong, dan Kalesaran 2017). YouTube juga melakukan pembaruan atas halaman My Videos yang berhubungan dengan cara pengguna dalam mengatur serta melakukan review atas video yang mereka unggah, termasuk pilihan untuk menyusun video secara alphabetis, berdasarkan durasi atau berdasarkan views. Pengguna YouTube juga bisa melihat konten video yang telah dilihat, dibeli atau berbagai video yang mereka sukai, yang tampilannnya ada di sebelah kiri halaman My Video. Jika ingin melakukan penambahan keterangan pada video, atau menambahkan teks pada video, serta melakukan unduhan file sebagai MP4, pilihan menu atas fitur ini, kini bisa ditemukan disebelah tab 'edit' (Mangole, Himpong, dan Kalesaran 2017).

Platform media sosial Youtube ini hanya salah satu platform media sosial yang ada di dunia dan hanya salah satu dari sekian banyak nya platform yang ada pada saat ini. Youtube sangat dirasakan manfaat nya dalam dunia perindustrian di bidang teknologi. Oleh sebab itu, banyak akun Youtube atau biasa disebut akun Youtuber yang dapat dihitung kualitas dan kredibilitas masing- masing akun mereka. Kredibilitas sebuah akun Youtube diukur dari performa dari masing- masing akun Youtube yang ada. Mengukur performa memerlukan pengukuran yang dimana berupa rasio.

\section{METODE PENELITIAN}

Penelitian kali ini memakai metode penelitian eksploratif dan kuantitatif agar dapat mengetahui kredibilitas dari performa akun Youtube 5 Youtuber Gaming Indonesia dengan Penghasilan Tinggi. Metode kuantitatif adalah pendekatan penelitian yang mewakili paham positivism (Kuantitatif, n.d.). Metode eksploratif adalah. termasuk dalam jenis penelitian sosial yang bertujuan untuk memberikan arti / definisi dan penjelasan mengenai konsep maupun pola yang digunakan dalam penelitian itu sendiri (Com dan Pengertian 2020). 
Penelitian ini bertujuan untuk mengetahui nilai kredibillitas dari performa akun Youtube 5 Youtuber Gaming Indonesia dengan Penghasilan Tinggi. Adapun langkah- langkah yang wajib dilalui dalam penelitian ini yaitu :

\section{1) Melakukan Eksplorasi Pada Website Untuk Menentukan Objek yang Akan Dianalisa}

Hal ini dilakukan di beberapa halaman website yang menyediakan informasi mengenai objek yang akan di teliti, sehingga ditemukan nama- nama akun Youtuber Gaming yang akan dijadikan objek analisa. Selanjutnya yaitu mencari nama akun Youtube dari masingmasing akun Youtuber Gaming. Pastikan semua akun Youtuber Gaming memiliki akun pada aplikasi sosial media Youtube.

2) Menghitung Nilai Rata-Rata Variable Dari 5 Youtuber Gaming Indonesia dengan Penghasilan Tinggi.

Peneliti menghitung nilai variable video comments dan juga variable video views. Variabel merupakan suatu objek yang diteliti atau diamati dalam penelitian.(Post, Adsense, dan Adalah, n.d.). Cara untuk menghitung nilai rata- rata dari variabel video comments dan variabel video views yaitu mengambil minimal 10 postingan. Setelah itu, dihitung untuk menemukan nilai rata- rata tiap variabel.

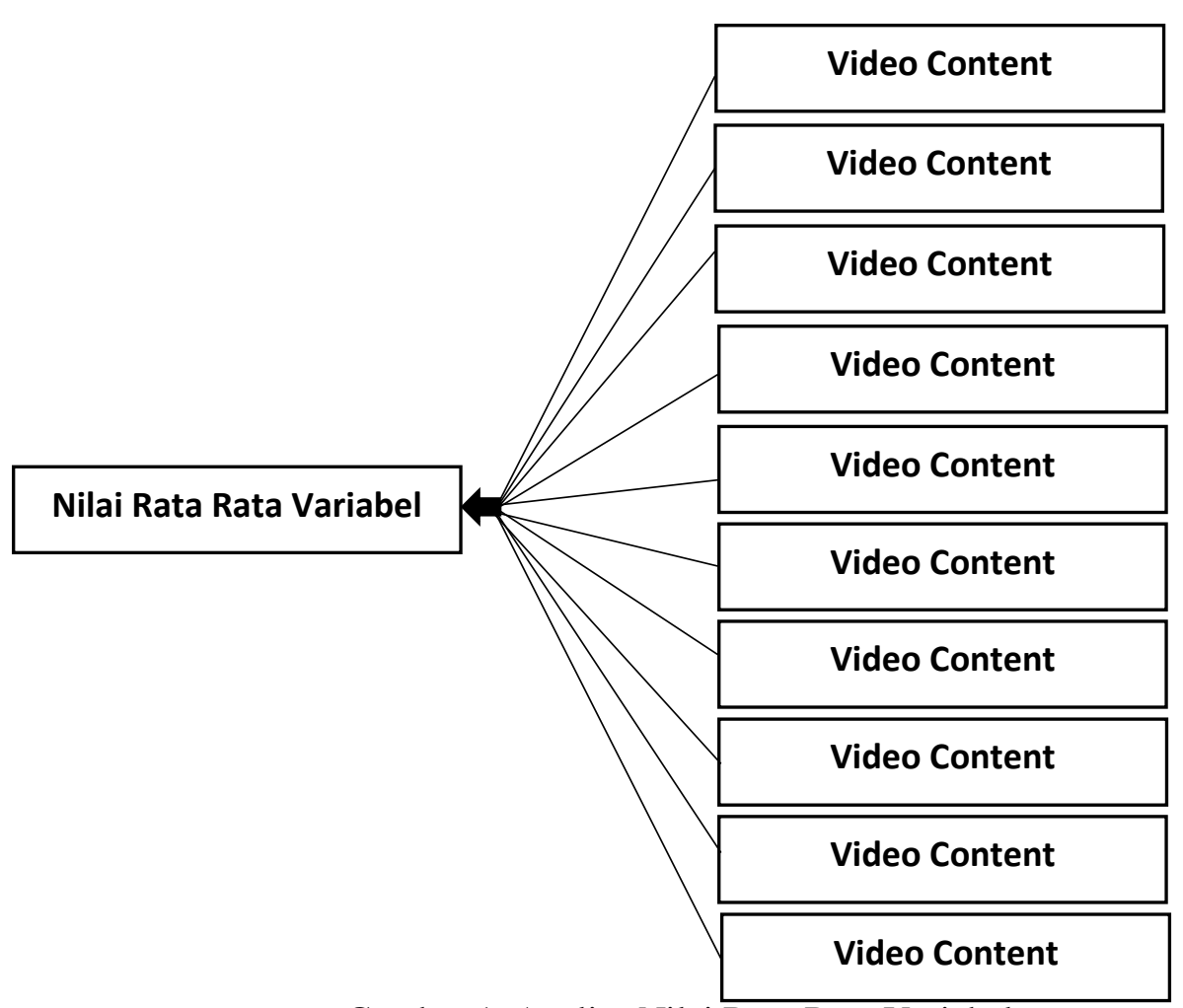

Gambar 1. Analisa Nilai Rata-Rata Variabel. 


\section{3) Menghitung Nilai Kredibilitas Rasio}

Cara menghitung nilai kredibilitas dari video comments to video views ratio dengan cara membagi nilai variabel yang pertama dengan nilai variabel yang kedua. Jika video comments memiliki nilai 300 dan video views memiliki nilai 500, jadi cara nya yaitu 300 $: 500=0,6$.

\section{4) Menentukan Peringkat}

Langkah terakhir yaitu menentukan peringkat pada tiap rasio yang ada. Penentuan peringkat perlu melihat karakteristik dari rasio yang diteliti. Kalau rasio memiliki karakteritik tinggi, maka objek yang mendapatkan nilai tertinggi akan mendapatkan angka 5 dan objek yang mendapatkan nilai terendah akan mendapatkan angka 1. Kalua karakteristik rasio rendah, maka objek yang memiliki nilai terendah akan mendapatkan angka 5 dan objek yang memiliki nilai tertinggi akan mendapatkan angka 1. Setelah itu, sudah dapat disimpulkan objek yang mana mendapatkan peringkat 1 sampai dengan peringkat 5 .

\section{HASIL DAN PEMBAHASAN}

Akun Youtube dari 5 Youtuber Gaming Top di Indonesia dengan Penghasilan Tinggi, diantaranya :

\section{Jess No Limit}

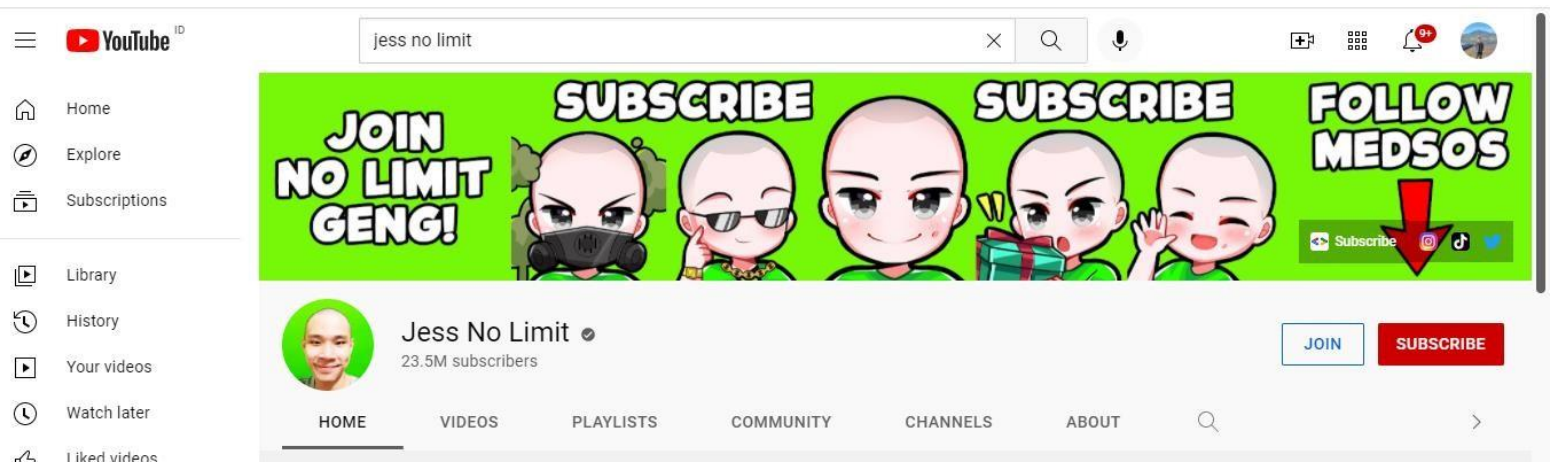

Gambar 2. Akun Youtube Jess No Limit

Sumber : https://www.youtube.com/c/JessNoLimit 
2. MiawAug.
$\equiv$ VouTube
(1) Home
(J) Explore
产 Subscriptions
$\square \quad$ Library
(5) History
$\rightarrow$ Your videos
(C) Watch later
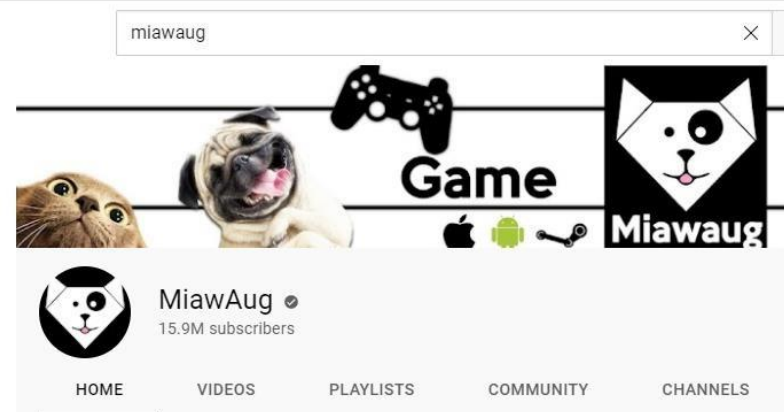

† 㗊

Gambar 3. Akun Youtube MiawAug.

Sumber : https://www.youtube.com/c/Miawaug 


\section{Tara Arts Game Indonesia}
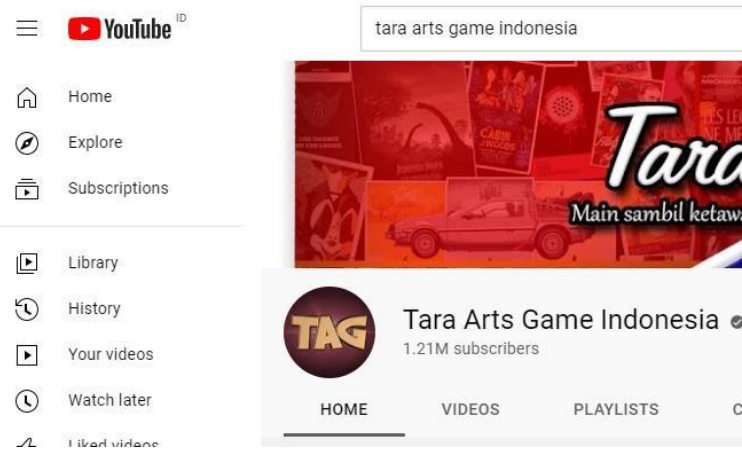

Gambar 4. Akun Youtube Tara Arts Game Indonesia

Sumber : https://www.youtube.com/user/TaraArtsDrawing

\section{Dylan PROS}
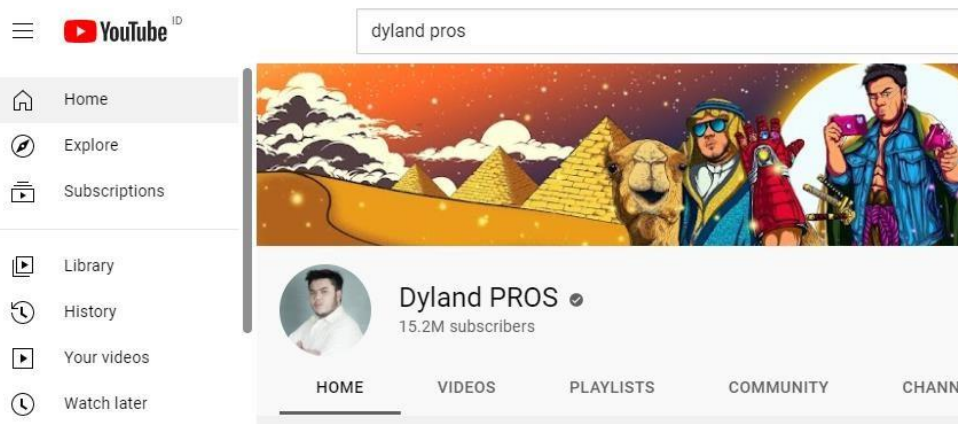
$\times \quad a \quad 0$

车 路
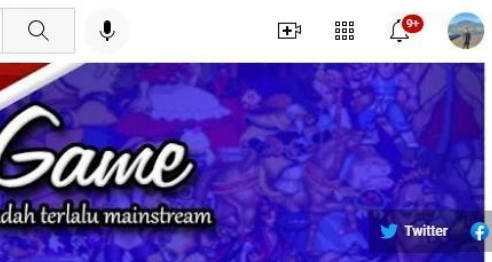

(1) Watch later

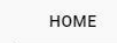

VIDEOS PLAYLISTS COMMUNITY CHANNELS

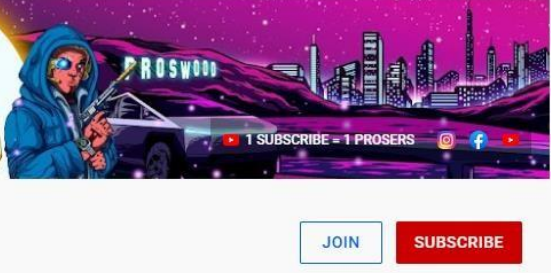

Gambar 5. Akun Youtube Dylan PROS

Sumber : https://www.youtube.com/c/DylandPROS

\section{Kemas pakai $Z$}
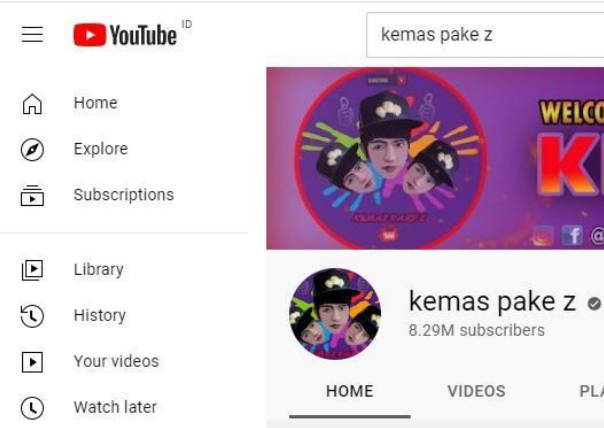

$\times \quad Q \quad y$

田

Gambar 6. Akun Youtube Kemas pakai Z

Sumber : https://www.youtube.com/c/kemaspakezmantapkali 
Dari kelima akun Youtube 5 Youtuber Gaming Top di Indonesia dengan Penghasilan Tinggi, peneliti menemukan nilai dari masing- masing variabel yang ada untuk menghitung rasio Video Comments to Video Views dari setiap akun. Pada akun Youtube terdapat 7 variabel, yaitu:

1. Likes

2. Subscribe

3. Video Like

4. Video Dislike

5. Video Views

6. Video Share

7. Video Comments

Dari ketujuh variable tersebut peneliti hanya fokus untuk menemukan hasil dari 2 variabel,yaitu:

\section{Video Comments}

2. Video Views

Dari kedua variabel tersebut kemudian dianalisa sehingga menemukan nilai rata- rata dari variabel video comments dan variabel video views. Untuk menghitung nilai rata- rata dari variabel video comments dan variabel video views yaitu dengan cara mengambil minimal 10 postingan kemudian dihitung sehingga menemukan nilai rata- rata dari masing- masing variabel. Berikut merupakan tabel nilai rata- rata dari masing- masing youtuber gaming di Indonesia dengan penghasilan tinggi, yaitu : 
Tabel 1. Analisa Nilai Rata- Rata nilai Variabel Video Comments dan Video Views Akun Youtube Jess No Limit

\begin{tabular}{|c|c|r|r|}
\hline 3 & \multicolumn{2}{|l|}{ Jess No Limit } & \\
\hline 4 & No & Video Comments & Video Views \\
\hline 5 & $\mathbf{1}$ & 2,658 & 365,631 \\
\hline 6 & $\mathbf{2}$ & 1,749 & 393,166 \\
\hline 7 & $\mathbf{3}$ & 2,330 & 466,767 \\
\hline 8 & $\mathbf{4}$ & 1,612 & 336,395 \\
\hline 9 & $\mathbf{5}$ & 1,622 & 264,105 \\
\hline 10 & $\mathbf{6}$ & 1,351 & 256,159 \\
\hline 11 & $\mathbf{7}$ & 2,796 & 664,545 \\
\hline 12 & $\mathbf{8}$ & 1,902 & 334,767 \\
\hline 13 & $\mathbf{9}$ & 1,873 & 410,375 \\
\hline 14 & $\mathbf{1 0}$ & 1,539 & 303,124 \\
\hline 15 & Total & $\mathbf{1 , 9 4 3}$ & $\mathbf{3 7 9 , 5 0 3}$ \\
\hline
\end{tabular}

Tabel 1

Sumber : Pengolahan Data Excel

Tabel 2. Analisa Nilai Rata- Rata Nilai Variabel Video Comments dan Video Views Akun Youtube MiawAug.

\begin{tabular}{|r|r|r|r|}
\hline 17 & MiawAug. & \\
\hline 18 & No & Video Comments & Video Views \\
\hline 19 & $\mathbf{1}$ & 5,364 & 464,461 \\
\hline 20 & $\mathbf{2}$ & 5,810 & 514,692 \\
\hline 21 & $\mathbf{3}$ & 7,439 & 897,696 \\
\hline 22 & $\mathbf{4}$ & 3,810 & 770,123 \\
\hline 23 & $\mathbf{5}$ & 7,313 & $1,057,016$ \\
\hline 24 & $\mathbf{6}$ & 3,881 & 745,420 \\
\hline 25 & $\mathbf{7}$ & 3,099 & 502,149 \\
\hline 26 & $\mathbf{8}$ & 11,202 & $3,836,306$ \\
\hline 27 & $\mathbf{9}$ & 1,253 & 269,761 \\
\hline 28 & $\mathbf{1 0}$ & 3,380 & 663,474 \\
\hline 29 & Total & $\mathbf{5 , 2 5 5}$ & $\mathbf{9 7 2 , 1 1 0}$ \\
\hline
\end{tabular}

Tabel 2

Sumber : Pengolahan Data Excel 
Tabel 3. Analisa Nilai Rata Nilai Variabel Video Comments dan Video Views Akun Youtube Tara Arts Game Indonesia

\begin{tabular}{|l|c|r|r|}
\hline 31 & \multicolumn{3}{|c|}{ Tara Arts Game Indoneisa } \\
\hline 32 & No & Video Comments & Video Views \\
\hline 33 & $\mathbf{1}$ & 881 & 16,573 \\
\hline 34 & $\mathbf{2}$ & 383 & 202,195 \\
\hline 35 & $\mathbf{3}$ & 586 & 103,017 \\
\hline 36 & $\mathbf{4}$ & 690 & 141,518 \\
\hline 37 & $\mathbf{5}$ & 108 & 101,260 \\
\hline 38 & $\mathbf{6}$ & 451 & 74,003 \\
\hline 39 & $\mathbf{7}$ & 1,137 & 309,007 \\
\hline 40 & $\mathbf{8}$ & 807 & 143,215 \\
\hline 41 & $\mathbf{9}$ & 361 & 66,593 \\
\hline 42 & $\mathbf{1 0}$ & 1,118 & 216,470 \\
\hline 43 & Total & $\mathbf{6 5 2}$ & $\mathbf{1 3 7 , 3 8 5}$ \\
\hline & & Tabel 3 & \\
\hline
\end{tabular}

Sumber : Pengolahan Data Excel

Tabel 4. Analisa Nilai Rata- Rata Nilai Variabel Video Comments dan Video Views Akun Youtube Dylan PROS

\begin{tabular}{|l|c|r|r|}
45 & \multicolumn{2}{l|}{ Dyland Pros } & \\
\hline 46 & No & Video Comments & Video Views \\
\hline 47 & $\mathbf{1}$ & 469 & 48,509 \\
\hline 48 & $\mathbf{2}$ & 738 & 146,188 \\
\hline 49 & $\mathbf{3}$ & 1,714 & 551,714 \\
\hline 50 & $\mathbf{4}$ & 624 & 90,371 \\
\hline 51 & $\mathbf{5}$ & 846 & 124,525 \\
\hline 52 & $\mathbf{6}$ & 1,591 & 182,238 \\
\hline 53 & $\mathbf{7}$ & 719 & 130,802 \\
\hline 54 & $\mathbf{8}$ & 1,362 & 258,052 \\
\hline 55 & $\mathbf{9}$ & 1,459 & 203,096 \\
\hline 56 & $\mathbf{1 0}$ & 3,649 & 314,455 \\
\hline 57 & Total & $\mathbf{1 , 3 1 7}$ & $\mathbf{2 0 4 , 9 9 5}$ \\
\hline & & &
\end{tabular}

Tabel 4

Sumber : Pengolahan Data Excel 
Tabel 5. Analisa Nilai Rata- Rata Nilai Variabel Video Comments dan Video Views Akun Youtube Kemas pakai Z

\begin{tabular}{|l|c|r|r|}
\hline 59 & \multicolumn{2}{|l|}{ Kemas Pakai Z } & \\
\hline 60 & No & Video Comments & Video Views \\
\hline 61 & $\mathbf{1}$ & 305 & 24,812 \\
\hline 62 & $\mathbf{2}$ & 437 & 71,198 \\
\hline 63 & $\mathbf{3}$ & 1,094 & 392,258 \\
\hline 64 & $\mathbf{4}$ & 1,568 & 267,484 \\
\hline 65 & $\mathbf{5}$ & 1,936 & 486,464 \\
\hline 66 & $\mathbf{6}$ & 244 & 37,004 \\
\hline 67 & $\mathbf{7}$ & 275 & 45,677 \\
\hline 68 & $\mathbf{8}$ & 817 & 242,443 \\
\hline 69 & $\mathbf{9}$ & 169 & 19,390 \\
\hline 70 & $\mathbf{1 0}$ & 230 & 28,719 \\
\hline 71 & Total & $\mathbf{7 0 8}$ & $\mathbf{1 6 1 , 5 4 5}$ \\
\hline & & Tabel 5 & \\
\hline
\end{tabular}

Sumber : Pengolahan Data Excel

Setelah menghitung nilai rata- rata tersebut, maka akan menemukan hasil akhir nilai rata- rata dari variabel video comments dan video views.

Tabel 6. Nilai Variabel Pada Akun Youtube 5 Youtuber Gaming Top di Indonesia dengan

Pengahsilan Tinggi

\begin{tabular}{|c|c|c|c|c|c|c|}
\hline 1 & \multirow{2}{*}{\multicolumn{6}{|c|}{ Tabel Nilai masing- Masing Variabel }} \\
\hline 2 & & & & & & \\
\hline 3 & Variabel & Jess No Limit & MiaAug. & Tara Arts Game Indonesia & Dyland Pros & Kemas Pakai Z \\
\hline 4 & Video Comments & 1,943 & 5,255 & 652 & 1,317 & 708 \\
\hline 5 & Video Views & 379,503 & 972,110 & 137,385 & 204,995 & 161,545 \\
\hline
\end{tabular}

Tabel 6

Sumber : Pengolahan Data Excel

Peneliti kali ini hanya berfokus untuk menghitung Video Comments to Video Views Ratio. Untuk menghitung kredibilitas dari masing- masing akun Youtube setiap Youtuber Gaming, peneliti menghitung dengan cara : variabel 1 akan dibagi dengan variabel 2, sehingga ditemukan hasil analisisa dari rasio tersebut. 
Tabel 7. Hasil Perhitungan Rasio Akun Youtube

\begin{tabular}{|c|c|c|c|r|c|r|}
\hline No & Ratio & Jess No Limit & MiawAug. & Tata Arts Game Indonesia & Dyland Pros & \multicolumn{1}{c|}{ Kemas Pakai Z } \\
\hline 1 & Video Comments to Video Views & 0.00511985413 & 0.00540576684 & 0.00474578739 & 0.00642454694 & 0.00438267975 \\
\hline \multicolumn{6}{|c|}{ Tabel 7 }
\end{tabular}

Sumber : Pengolahan Data Excel

Video Comments to Video Views Ratio memiliki karakteristik yang tinggi, artinya semakin tinggi nilai yang dihasilkan maka akan semakin baik kredibilitas dari performa akun tersebut. Untuk memberikan peringkat pada masing- masing Youtuber Gaming, peneliti memberikan angka 5 kepada Youtuber yang mendapatkan bilai terendah. Berikut merupakan tabel urutan nilai yang dihasilkan oleh masing- masing Youtuber Gaming. 
Tabel 8. Nilai Rasio Akun Youtube 5 Youtuber Gaming Top di

Indonesia denganPenghasilan Tinggi

Tabel Peringkat

\begin{tabular}{|c|c|c|c|c|c|}
\hline Karakteristik & Jess No Limit & MiawAug. & Tara Arts Game Indonesia & Dyland Pros & Kemas Pakai Z \\
\hline Tinggi & 4 & 5 & 2 & 3 & 1 \\
\hline & $\mathbf{4}$ & $\mathbf{5}$ & $\mathbf{2}$ & $\mathbf{3}$ & $\mathbf{1}$ \\
\hline
\end{tabular}

Tabel 8

Sumber : Pengolahan Dta Excel

Dari tabel Nilai Rasio Akun Youtube 5 Youtuber Gaming Top di Indonesia dengan PenghasilanTinggi dapat disimpulkan bahwa MiawAug. Mendapatkan nilai tertinggi untuk rasio Video Comments to Video Views. Sedangkan akun Youtube Kemas pakai Z mendapatkan nilai terendah untuk rasio ini. Jadi, pada penelitian ini MiawAug. Memiliki kredibilitas performa yang lebih baik dibandingkan dengan Youtuber Gaming lainnya.

\section{KESIMPULAN}

Penelitian ini memiliki tujuan yang dimana untuk mengetahui kredibilitas performa dari akun Youtube 5 Youtuber Gaming Top di Indonesia dengan Penghasilan Tinggi menggunakan Video Comments to Video Views Ratio. 5 Youtuber Gaming Top di Indonesia dengan Penghasilan Tinggi tersebut diantaranya : Jess No Limit, MiawAug., Tara Arts Game Indonesia, Dylan PROS dan Kemas pakai Z. Dari kelima akun Youtuber Gaming tersebut disimpulkan bahwa :

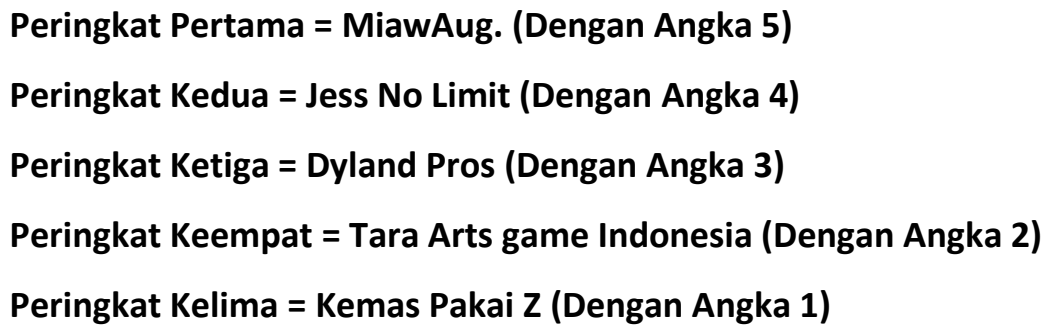




\section{DAFTAR PUSTAKA}

Com, Rapikan, dan Penelitian Eksploratif Pengertian. 2020. "Rapikan.com."

Hendika Permana, I Putu. 2021. “Analisis Rasio Pada Akun Youtube Untuk Penelitian Kualitatif Menggunakan Metode Ekploratif.” Jurnal Ilmiah Media Sisfo 15 (1): 40.

https://doi.org/10.33998/mediasisfo.2021.15.1.970.

Kuantitatif, Metode Penelitian. n.d. "Play Free Games with Friends Play Free Games with Friends."

Mangole, Kevin David B., Meity Himpong, dan Edmon R. Kalesaran. 2017. "Pemanfaatan Youtube dalam Meningkatkan Pengetahuan Masyarakat di Desa Paslaten Kecamatan Remboken Minahasa." Jurnal Acta Diurna 6 (4): 1-15.

https://ejournal.unsrat.ac.id/index.php/actadiurnakomunikasi/article/download/18359/17887.

Post, Recent, Google Adsense, dan Napza Adalah. n.d. "Variabel Penelitian Adalah" 5.

Suarasumsel.com. 2021. “Aplikasi Oxtrade Ini 5 YouTuber Gaming Paling Top di Indonesia, Penghasilan Tinggi” 5 (5 Youtuber Gaming Paling Top di Indoneisa Penghasilan Tinggi): 5. https://sumsel.suara.com/read/2021/10/04/130633/ini-5-youtuber-gaming-paling-top-diindonesia-penghasilan-tinggi?page $=1$.

Com, Rapikan, dan Penelitian Eksploratif Pengertian. 2020. "Rapikan.com."

Hendika Permana, I Putu. 2021. “Analisis Rasio Pada Akun Youtube Untuk Penelitian Kualitatif Menggunakan Metode Ekploratif.” Jurnal Ilmiah Media Sisfo 15 (1): 40. https://doi.org/10.33998/mediasisfo.2021.15.1.970.

Kuantitatif, Metode Penelitian. n.d. "Play Free Games with Friends Play Free Games with Friends."

Mangole, Kevin David B., Meity Himpong, dan Edmon R. Kalesaran. 2017. "Pemanfaatan Youtube dalam Meningkatkan Pengetahuan Masyarakat di Desa Paslaten Kecamatan Remboken Minahasa.” Jurnal Acta Diurna 6 (4): 1-15.

https://ejournal.unsrat.ac.id/index.php/actadiurnakomunikasi/article/download/18359/17 887.

Post, Recent, Google Adsense, dan Napza Adalah. n.d. "Variabel Penelitian Adalah" 5. Suarasumsel.com. 2021. “Aplikasi Oxtrade Ini 5 YouTuber Gaming Paling Top di Indonesia, Penghasilan Tinggi” 5 (5 Youtuber Gaming Paling Top di Indoneisa Penghasilan Tinggi): 5. https://sumsel.suara.com/read/2021/10/04/130633/ini-5-youtuber-gaming- 
paling-top-di-indonesia-penghasilan-tinggi page $=1$.

Com, Rapikan, dan Penelitian Eksploratif Pengertian. 2020. "Rapikan.com.”

Hendika Permana, I Putu. 2021. “Analisis Rasio Pada Akun Youtube Untuk Penelitian Kualitatif Menggunakan Metode Ekploratif.” Jurnal Ilmiah Media Sisfo 15 (1): 40. https://doi.org/10.33998/mediasisfo.2021.15.1.970.

Kuantitatif, Metode Penelitian. n.d. "Play Free Games with Friends Play Free Games with Friends."

Mangole, Kevin David B., Meity Himpong, dan Edmon R. Kalesaran. 2017. "Pemanfaatan Youtube dalam Meningkatkan Pengetahuan Masyarakat di Desa Paslaten Kecamatan Remboken Minahasa.” Jurnal Acta Diurna 6 (4): 1-15. https://ejournal.unsrat.ac.id/index.php/actadiurnakomunikasi/article/download/18359/17 887.

Post, Recent, Google Adsense, dan Napza Adalah. n.d. "Variabel Penelitian Adalah" 5.

Suarasumsel.com. 2021. “Aplikasi Oxtrade Ini 5 YouTuber Gaming Paling Top di Indonesia, Penghasilan Tinggi" 5 (5 Youtuber Gaming Paling Top di Indoneisa Penghasilan Tinggi): 5. https://sumsel.suara.com/read/2021/10/04/130633/ini-5-youtuber-gamingpaling-top-di-indonesia-penghasilan-tinggi?page $=1$. 